\title{
RISK FACTORS THE INCIDENCE OF MALARIA IN THE DISTRICT OF KEMIRI PURWOREJO REGENCY
}

\author{
Lilik Setyowatiningsih $^{\mathrm{a}^{*}}$;Surati Surati ${ }^{\mathrm{b}}$ \\ ${ }^{a, b}$ Department of Health Analyst ; Poltekkes Kemenkes Semarang \\ 115 Wolter Monginsidi Street ; Semarang 50192 ; Indonesia
}

\begin{abstract}
Malaria is caused by protozoa of the genus plasmodium which infect red blood cells. Malaria cases in Kemiri Subdistrict, Purworejo Regency in 2006 were 13 cases and in 2016 malaria reappeared with 44 cases. The purpose of this study was to determine the risk factors associated with the incidence of malaria in Kemiri District, Purworejo Regency. The benefits of this research are adding information to the public about risk factors associated with malaria in the Kemiri District, Purworejo Regency. This type of research is observational research with analytic criteria. The variables of this study are malaria incidence and risk factors which include education, knowledge, employment, use of mosquito nets and environmental sanitation. The population and sample in this study were citizens in the Kemiri District, Purworejo Regency. Based on the results of laboratory tests all respondents (87 people) $100 \%$ tested negative for malaria. Bivariate test results showed that there was no significant relationship between the incidence of malaria with education $(p=0.845)$, knowledge $(p=0.359)$, community behavior $(p=0.524)$ and environmental sanitation $(\mathrm{p}=0.095)$.
\end{abstract}

Keywords: risk factors; malaria incidence; plasmodium

\section{Introduction}

Malaria is caused by protozoa of the genus Plasmodium which infect red blood cells. There are five Plasmodium species namely Plasmodium falciparum, Plasmodium vivax, Plasmodium ovale, Plasmodium malariae, and Plasmodium knowlesi (Supranelfy et al., 2018). Ministry of Health Republic of Indonesia, 2006, Plasmodium parasites that live and develop in human red blood cells are transmitted through the bite of female Anopheles mosquitoes (Faizah \& Fibriana, 2016).

Malaria has attacked 106 countries in the world. One of the common goals in the global commitment that must be achieved by 2015 on the Millennium Development Goals (MDGs) is the effort to eradicate malaria. After the end of the 2015 MDGs, global commitments are continued through Sustainable Development Goals (SDGs) and efforts to eradicate malaria are

\footnotetext{
*) Corresponding Author (Lilik Setyowatiningsih)

E-mail: liliksetyowati70@gmail.com
}

in the third goal of ensuring healthy lives and seeking prosperity for all, with the specific goal of ending the AIDS epidemic, tuberculosis, malaria, neglected diseases -tropical until 2030 (Kemenkes RI, 2016).

Purworejo is one of the malaria endemic districts in Central Java. There were 728 malaria cases in 2013, an increase in 2014 that was 803 cases (Dinas Kesehatan Kabupaten Purworejo, 2015). Malaria cases in Puskesmas Winong, Kemiri Subdistrict, Purworejo Regency in 2006 were 0.66 per million with a total of 13 cases and as of 2015 there were no cases. In 2016 malaria reappeared with an API of 2.3 per mil with a total of 44 cases from microscopic blood test results. Malaria occurs in four villages, namely: Girijoyo, Turus, Girimulyo and Winong. Most malaria cases were in Turus Village with 17 cases while the smallest was in Winong Village, 1 case (Nababan \& Umniyati, 2018).

Ensuring that malaria cases remain low requires efforts to maintain cases so as not to increase again such as early discovery and 
appropriate case management. Imported malaria cases in late receptive areas are very potential to cause local transmission (indigenous) and even an increase in cases or external events. Ordinary (KLB) (Dinkes Provinsi Jateng, 2019).

\section{Method}

This study was an observational study with analytical research criteria and used a Case control design. The design was chosen because it is able to assess the relationship between risk factors and the consequences that occur in the form of malaria at one time. The questionnaire as an observation instrument to describe, community characteristics, knowledge about malaria incidence, community behavior and environmental sanitation associated with malaria.

Data collected in this study include primary data. Primary data is malaria incidence data obtained from the results of laboratory tests of thick and thin blood preparations using the slide test method using capillary blood. Whereas to find out malaria risk factors obtained from direct interviews and questionnaires covering education, knowledge, behavior and environmental sanitation in the community of Kemiri District, Purworejo Regency. The tools used in this study are lancets, glass objects, microscopes. The material used is capillary blood. The reagents used were giemsa, cotton alcohol and ethanol.

\section{Result and Discussion}

Respondents distribution is grouped by sex, education and occupation which aims to see the magnitude of the risk of malaria exposure in each group.

Table 1. Characteristics of respondents

\begin{tabular}{lcc}
\hline Characteristics & Total & Percentage \\
\hline Age(years) : Mean/SD & & $45.35 \pm 20.031$ \\
Sex & & 42.5 \\
$\quad$ Male & 37 & 57.5 \\
$\quad$ Female & 50 & \\
Education & & 26.4 \\
$\quad$ None & 23 & 43.7 \\
$\quad$ Primary school & 38 & 11.5 \\
$\quad$ Junior high school & 10 & 18.4 \\
$\quad$ High school & 16 & \\
Profession & & 28.7 \\
$\quad$ Unemploymen & 25 & 60.9 \\
$\quad$ Farmer & 53 & 2.3 \\
$\quad$ Laborer & 2 & 1.2 \\
$\quad$ Government & 1 & \\
$\quad$ Employees & & 6.9 \\
$\quad$ Student & 6 &
\end{tabular}

Based on the results of laboratory examinations (Table 2) which included thick and thin blood preparations in the community of Kemiri Subdistrict, Purworejo Regency as many as 87 people $(100 \%)$ consisting of 29 people as cases and 58 people as controls were stated negative for the incidence of malaria.

Table 2. Malaria examination results

\begin{tabular}{ccccccc}
\hline \multirow{2}{*}{$\begin{array}{c}\text { Examination } \\
\text { Result }\end{array}$} & \multicolumn{4}{c}{ Group } & \multirow{2}{*}{ Total } \\
\cline { 2 - 6 } & \multicolumn{2}{c}{ Case } & \multicolumn{2}{c}{ Control } & & \\
\cline { 2 - 6 } & $\mathrm{n}$ & $\%$ & $\mathrm{n}$ & $\%$ & $\mathrm{n}$ & $\%$ \\
\hline Positive & 0 & 0 & 0 & 0 & 0 & 0 \\
Negative & 29 & 100 & 58 & 100 & 87 & 100 \\
\hline
\end{tabular}

This is because the Purworejo District Government has carried out a malaria elimination program by forming a Village Malaria Interpreter (JMD) at each Puskesmas tasked with monitoring and conducting free malaria checks for local people and migrants suspected of suffering from malaria and reporting every case to the Purworejo District Health Office. This program is very effective in eliminating malaria prevalence in Purworejo District. Previously it was known that the number of Malaria cases in Purworejo Regency was caused by imported malaria cases brought by migrants or transmigrants who came or returned to Purworejo. This result is in line with the results of the research of (Puasa et al., 2018) which states that malaria is not found positive in the community of Bringin Jaya Village, Oba Tengah District, Tidore City.

Table 3. Recapitulation of respondents' knowledge

\begin{tabular}{lcccccc}
\hline & \multicolumn{5}{c}{ Group } & \multicolumn{2}{c}{ Total } \\
\cline { 2 - 5 } Knowledge & \multicolumn{2}{c}{ Case } & \multicolumn{2}{c}{ Control } & & \\
\cline { 2 - 5 } & $\mathrm{n}$ & $\%$ & $\mathrm{n}$ & $\%$ & $\mathrm{n}$ & $\%$ \\
\hline Malaria disease & & & & & & \\
$\quad$ Unknown & 9 & 31 & 13 & 22.4 & 22 & 25.3 \\
$\quad$ Known & 20 & 69 & 45 & 77.6 & 65 & 74.7 \\
Malaria spread & & & & & & \\
$\quad$ Unknown & 9 & 31 & 12 & 20.7 & 21 & 24.1 \\
$\quad$ Known & 20 & 69 & 46 & 79.3 & 66 & 75.9 \\
Malaria & & & & & & \\
symptom & 8 & 27.6 & 10 & 17.2 & 18 & 20.7 \\
$\quad$ Unknown & 21 & 72.4 & 48 & 82.8 & 69 & 79.3 \\
$\quad$ Known & & & & & & \\
Malaria & & & & & & \\
Prognosis & 11 & 37.9 & 14 & 24.1 & 25 & 28.7 \\
$\quad$ Unknown & 18 & 62.1 & 44 & 75.9 & 62 & 71.3 \\
$\quad$ Known & & & & & & \\
Prevention of & & & & & & \\
Malaria & 6 & 20.7 & 11 & 19 & 17 & 19.5 \\
$\quad$ Unknown & 23 & 79.3 & 47 & 81 & 70 & 80.5 \\
$\quad$ Known & & & & & &
\end{tabular}




\begin{tabular}{lcccccc}
\hline \multirow{2}{*}{ Knowledge } & \multicolumn{9}{c}{ Group } & \multirow{2}{*}{ Total } \\
\cline { 2 - 5 } & \multicolumn{2}{c}{ Case } & \multicolumn{2}{c}{ Control } & \multicolumn{2}{c}{} \\
\cline { 2 - 5 } & $\mathrm{n}$ & $\%$ & $\mathrm{n}$ & $\%$ & $\mathrm{n}$ & $\%$ \\
\hline Fogging benefits & & & & & & \\
$\quad$ Unknown & 6 & 20.7 & 11 & 19 & 17 & 19.5 \\
$\quad$ Known & 23 & 79.3 & 47 & 81 & 70 & 80.5 \\
\hline Malaria & & & & & & \\
transmission & 6 & 20.7 & 11 & 19 & 17 & 19.5 \\
$\quad$ Unknown & 23 & 79.3 & 47 & 81 & 70 & 80.5 \\
$\quad$ Known & & & & & & \\
Malaria & & & & & & \\
examination & 11 & 37.9 & 11 & 19 & 22 & 25.3 \\
$\quad$ Unknown & 18 & 62.1 & 47 & 81 & 65 & 74.7 \\
$\quad$ Known & & & & & & \\
Health worker & & & & & & \\
authority & & & & & & \\
$\quad$ Unknown & 17 & 58.6 & 39 & 67.2 & 56 & 64.4 \\
$\quad$ Known & 12 & 41.4 & 19 & 32.8 & 31 & 35.6 \\
Benefits of & & & & & & \\
Extension & & & & & & \\
$\quad$ Unknown & 2 & 6.9 & 5 & 8.6 & 7 & 8 \\
$\quad$ Known & 27 & 93.1 & 53 & 91.4 & 80 & 92 \\
\hline
\end{tabular}

Based on table 3. It can be concluded that most of the case and control group respondents have good knowledge about malaria.

Table 4. Recapitulation of community behavior

\begin{tabular}{|c|c|c|c|c|c|c|}
\hline \multirow{3}{*}{ Behavior } & \multicolumn{4}{|c|}{ Group } & \multirow{2}{*}{\multicolumn{2}{|c|}{ Total }} \\
\hline & \multicolumn{2}{|c|}{ Case } & \multicolumn{2}{|c|}{ Control } & & \\
\hline & $\mathrm{n}$ & $\%$ & $\mathrm{n}$ & $\%$ & $\mathrm{n}$ & $\%$ \\
\hline \multicolumn{7}{|c|}{ Use mosquito net } \\
\hline No & 3 & 10.3 & 7 & 12.1 & 10 & 11.5 \\
\hline Yes & 26 & 89.7 & 51 & 87.9 & 77 & 88.5 \\
\hline \multicolumn{7}{|l|}{ Use mosquito } \\
\hline rappelent & 15 & 51.7 & 40 & 69 & 55 & 63.2 \\
\hline $\begin{array}{l}\text { No } \\
\text { Yes }\end{array}$ & 14 & 48.3 & 18 & 31 & 32 & 36.8 \\
\hline \multicolumn{7}{|c|}{ Use Night gown } \\
\hline No & 7 & 24.1 & 22 & 37.9 & 29 & 33.3 \\
\hline Yes & 22 & 75.9 & 36 & 62.1 & 58 & 66.7 \\
\hline \multicolumn{7}{|l|}{ Fogging } \\
\hline No & 0 & 0 & 0 & 0 & 0 & 0 \\
\hline Yes & 29 & 100 & 58 & 100 & 87 & 100 \\
\hline \multicolumn{7}{|l|}{ Night out } \\
\hline Yes & 11 & 37.9 & 18 & 31 & 29 & 33.3 \\
\hline No & 18 & 62.1 & 40 & 69 & 58 & 66.7 \\
\hline \multicolumn{7}{|l|}{ Extension } \\
\hline No & 0 & 0 & 0 & 0 & 0 & 0 \\
\hline Yes & 29 & 100 & 58 & 100 & 87 & 100 \\
\hline
\end{tabular}

Based on table 4, it can be concluded that most of the case and control group respondents also had good behavior in preventing malaria.

Table 5. Recapitulation of community environmental sanitation

\begin{tabular}{cccccccc}
\hline \multirow{2}{*}{$\begin{array}{c}\text { Environmental } \\
\text { sanitation }\end{array}$} & \multicolumn{4}{c}{ Group } & \multirow{2}{*}{ Total } \\
\cline { 2 - 5 } & \multicolumn{2}{c}{ Case } & \multicolumn{2}{c}{ Control } & & \\
\cline { 2 - 5 } & $\mathrm{n}$ & $\%$ & $\mathrm{n}$ & $\%$ & $\mathrm{n}$ & $\%$ \\
\hline Having toilet & & & & & & \\
No & 1 & 3.4 & 2 & 3.4 & 3 & 3.4 \\
Yes & 28 & 96.6 & 56 & 96.6 & 84 & 96.6
\end{tabular}

\begin{tabular}{|c|c|c|c|c|c|c|}
\hline \multirow{3}{*}{$\begin{array}{l}\text { Environmental } \\
\text { sanitation }\end{array}$} & \multicolumn{4}{|c|}{ Group } & \multirow{2}{*}{\multicolumn{2}{|c|}{ Total }} \\
\hline & \multicolumn{2}{|c|}{ Case } & \multicolumn{2}{|c|}{ Control } & & \\
\hline & $\mathrm{n}$ & $\%$ & $\mathrm{n}$ & $\%$ & $\mathrm{n}$ & $\%$ \\
\hline \multicolumn{7}{|l|}{ Having trash can } \\
\hline No & 25 & 86.2 & 52 & 89.7 & 77 & 88.5 \\
\hline Yes & 4 & 13.8 & 6 & 10.3 & 10 & 11.5 \\
\hline \multicolumn{7}{|l|}{ Clean water } \\
\hline $\begin{array}{r}\text { No } \\
\text { No }\end{array}$ & 0 & 0 & 0 & 0 & 0 & 0 \\
\hline $\begin{array}{l}\text { No } \\
\text { Yes }\end{array}$ & 29 & 100 & 58 & 100 & 87 & 100 \\
\hline \multicolumn{7}{|l|}{ Have cattle pen } \\
\hline Yes & 14 & 48.3 & 35 & 60.3 & 49 & 56.3 \\
\hline No & 15 & 51.7 & 23 & 39.7 & 38 & 43.7 \\
\hline \multicolumn{7}{|l|}{ Near garden } \\
\hline Yes & 29 & 100 & 58 & 100 & 87 & 100 \\
\hline No & 0 & 0 & 0 & 0 & 0 & 0 \\
\hline
\end{tabular}

Based on table 5, it states that the majority of respondents already have good environmental sanitation for the prevention of malaria, but not many respondents have trash bins.

Table 6. Relationship between risk factors and malaria incidence

\begin{tabular}{|c|c|c|c|c|c|c|c|}
\hline \multirow{3}{*}{ Variable } & \multicolumn{4}{|c|}{ Group } & \multirow{3}{*}{ OR } & \multirow{3}{*}{ CI 95\% } & \multirow{3}{*}{$\begin{array}{l}P \\
\text { value }\end{array}$} \\
\hline & \multicolumn{2}{|c|}{ Case } & \multicolumn{2}{|c|}{ Control } & & & \\
\hline & $\mathrm{n}$ & $\%$ & $\mathrm{n}$ & $\%$ & & & \\
\hline \multicolumn{8}{|l|}{ Education } \\
\hline \\
\hline \multicolumn{8}{|l|}{ Junior } \\
\hline \multicolumn{8}{|l|}{ High } \\
\hline School & 24 & 82.8 & 47 & 81 & 1.123 & $0.350-$ & $0.845^{*}$ \\
\hline \multirow{2}{*}{\multicolumn{8}{|c|}{ Junior }} \\
\hline & & & & & & & \\
\hline \multirow{2}{*}{\multicolumn{8}{|c|}{$\begin{array}{l}\text { High } \\
\text { chool }\end{array}$}} \\
\hline & & & & & & & \\
\hline \multicolumn{8}{|l|}{ Knowledge } \\
\hline Bad & 8 & 27.6 & 11 & 19 & 1.628 & $0.5 / 2-$ & $0.359^{*}$ \\
\hline Good & 21 & 72.4 & 47 & 81 & & & \\
\hline \multicolumn{8}{|l|}{ Behavior } \\
\hline $\mathrm{Bad}$ & 5 & 17.2 & 7 & 12.1 & 1.518 & 0.437 - & $0.524^{* *}$ \\
\hline Good & 24 & 82.8 & 51 & 87.9 & & & \\
\hline \multicolumn{8}{|l|}{ Sanitation } \\
\hline $\mathrm{Bad}$ & 11 & 37.9 & 33 & 56.9 & 0.463 & 0.186 - & $0.095^{*}$ \\
\hline Good & 18 & 62.1 & 25 & 43.1 & & & \\
\hline
\end{tabular}

Table 6 states that the results of the analysis using the chi square test of education, knowledge and environmental sanitation variables show no significant relationship with the incidence of malaria $(p<0.05)$, while the analysis using the Fisher's exact test shows that there are no behavioral variables which was significant with the incidence of malaria $(\mathrm{p}<0.05)$.

The results of the analysis of the relationship between education and malaria incidence using the Chi square test obtained pvalue $=0.845(95 \% \mathrm{CI}=0.350-3.605 ; \mathrm{OR}=1.123)$. The p-value indicates there is no significant relationship between education and malaria incidence. This study is not in line with research 
on 180 communities in Kabola Subdistrict which states that there is a significant relationship between education and the incidence of malaria $(p=0.017)$ (Sir et al., 2015).

The results of the analysis of the relationship between knowledge and the incidence of malaria using the chi square test obtained $\mathrm{p}$-value $=0.359(95 \% \mathrm{CI}=0.572-4.633$; $\mathrm{OR}=1.628)$. The $\mathrm{p}$-value indicates there is no significant relationship between knowledge and the incidence of malaria. This study is in line with research conducted in the working area of

Teluk Pandan Public Health Center in Pesawaran Regency, Lampung Province which states that there is no significant relationship between knowledge and the incidence of malaria $(p=0.30)$ (Nurmaulina et al., 2018).

The results of the analysis of the relationship between behavior and the incidence of malaria using the fisher's exact test obtained $\mathrm{p}$-value $=0.524$ (95\% CI $=0.437-5.277 ; \mathrm{OR}=1.518)$. The $\mathrm{p}$-value indicates no significant relationship between behavior and the incidence of malaria. This study is not in line with research on 100 people in the work area of the Tombatu Minahasa Southeast Health Center which states there is a significant relationship between behavior and the incidence of malaria $(p=0.002)$ (Ajami et al., 2016).

The results of the analysis of the relationship between environmental sanitation with the incidence of malaria using the chi square test obtained p-value $=0.095 \quad(95 \%$ $\mathrm{CI}=0.186-1.153 ; \mathrm{OR}=0.463)$. The $\mathrm{p}$-value indicates that there is no significant relationship between environmental sanitation and the incidence of malaria. This study is in line with research conducted on 110 elementary school students in North Bolaang Mongondow Regency which stated that there was no significant relationship between environmental sanitation and malaria $(p=0.214)$ (Datukramat et al., 2013).

\section{Conclusion and Suggestion}

Based on the results of laboratory examinations, 87 respondents $(100 \%)$ including 29 case groups and 58 control groups tested negative for malaria infection.

There was no significant relationship between education $(p=0.845)$, knowledge $(p=0.359)$, community behavior $(p=0.524)$ and environmental sanitation $(p=0.095)$ with the incidence of malaria in Kemiri Subdistrict, Purworejo District.
Data analysis cannot proceed to the multivariate test because there are no risk factors that influence the incidence of malaria in Kemiri District, Purworejo Regency.

For the next research, it is suggested to conduct malaria examination using immunoserological methods to find out the malaria antibody titer in the respondent's body. Research respondents should be community members who have not been reached by health service facilities.

\section{Acknowledgments}

Many thanks were conveyed for the opportunity given to obtain the DIPA Risbinakes at Poltekkes Kemenkes Semarang so that this research could be completed.

\section{References}

Ajami, W. A., Ottay, R. I., \& Rombot, D. V. (2016). Hubungan Antara Perilaku Masyarakat dengan Kejadian Malaria di Wilayah Kerja Puskesmas Tombatu Kabupaten Minahasa Tenggara. Jurnal Kedokteran Komunitas Dan Tropik, 4(1), 65-72.

Datukramat, D., Mayulu, N., \& Masi, G. (2013). Hubungan Sanitasi Lingkungan Dengan Kejadian Malaria Pada Murid Sekolah Dasar Di Kabupaten Bolaang Mongondow Utara. Jurnal Keperawatan UNSRAT, 1(1), 112522.

Dinas Kesehatan Kabupaten Purworejo. (2015). Profil Kesehatan 2014 Menuju Purworejo Sehat.

http:/ / www.depkes.go.id/resources/dow nload/profil/PROFIL_KAB_KOTA_2014/3 306_Jateng_Kab_Purworejo_2014.pdf

Dinkes Provinsi Jateng. (2019). Profil Kesehatan Provinsi Jawa Tengah Tahun 2018.

Faizah, E. N., \& Fibriana, A. I. (2016). Hubungan Antara Status Medical Check Up Terhadap. Unnes Journal of Public Health, 5(1), 110119.

Kemenkes RI. (2016). InfoDatin-Malaria-2016.pdf (pp. 1-7).

Nababan, R., \& Umniyati, S. R. (2018). Analisis Spasial Kejadian Malaria Dan Habitat Larva Nyamuk Anopheles spp di Wilayah Kerja Puskesmas Winong Kabupaten Purworejo. Berita Kedokteran Masyarakat, 34(1),

11. https://doi.org/10.22146/bkm.26941

Nurmaulina, W., Kurniawan, B., \& Fakhruddin, H. (2018). Hubungan Pengetahuan, Sikap dan Perilaku Penderita Malaria Falciparum 
Dengan Derajat Infeksi di Wilayah Kerja Puskesmas Hanura Kecamatan Teluk Pandan Kabupaten Pesawaran Provinsi Lampung Relations Between Knowledge, Attitude and Behavior to Falciparum Ma. Majority, 7(3), 34-40.

Puasa, R., H, A. A., \& Kader, A. (2018). Identifikasi Plasmodium Malaria Didesa Beringin Jaya Kecamatan Oba Tengah Kota Tidore Kepulauan. Jurnal Riset Kesehatan,
$7(1)$

21.

https:// doi.org/10.31983/jrk.v7i1.3056

Supranelfy, Y., Warni, S. E., Inzana, N., \&Suryaningtyas, N. H. (2018). Penemuan Kasus Malaria Berdasarkan Pemeriksaan Mikroskopis di Kota Lubuklinggau dan Kabupaten Musi Rawas. ASPIRATOR Journal of Vector-Borne Disease Studies, 10(1), 27-36. https://doi.org/10.22435/asp.v10i1.15 